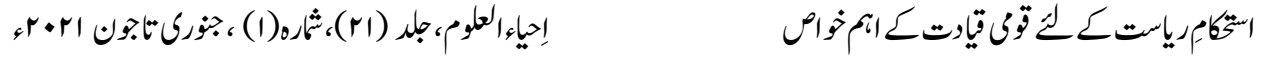

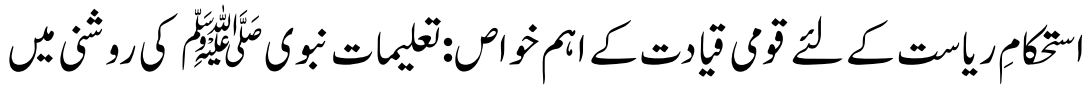

\section{The Characteristics of National Leadership for an Islamic State in the \\ Light of Teachings of Prophet Muhammad (PBUH)}

${ }^{*}$ Dr. Nighat Akram

${ }^{* *}$ Dr. Abdul Rehman Khan

\begin{abstract}
Allah sent a chain of Prophets with revelations to transfer humanity from a state of jāhiliyya to one of Islam. Allah says in the noble Qur'ān: "I have not created the Jinn and Ins (human beings) except to worship me" (Al-Qur'ān 51:56). Human beings must, therefore, live according to the laws of Allah. This can best be done in the framework of the Islamic state, the natural habitat of Muslims. Strengthen of a state depends upon best qualities of prime leaders. The purpose of this study is to determine the key attributes of the leaders and administrators in the light of the life of Holy Prophet (SAW), The paper has analyzed the concept of leadership as observed through literature survey about the leadership qualities of our beloved Holy Prophet Hazrat Muhammad (SAW), his Sahāba (R.A) by citing Qur'ānic verses and giving the examples from the life of Holy Prophet (SAW). The study has proposed a conceptual framework for an effective leader based upon the characteristics such as firmness, truthfulness, reliability, selflessness, ethics, loyalty to the organization, passion, moderation, humility, fairness and mercy which can be set as a role model for day's administrators etc.
\end{abstract}

Key Words: Holy prophet, Leadership, Islamic State, administration, model

* Assistant Professor, Department of Islamic Studies, University of Poonch, Rawalakot. Ajk. nighatakram @upr.edu.pk

** Assistant Professor, Department of Islamic Studies, University of Poonch,Rawalakot. Ajk. drabdulrehmank@upr.edu.pk 


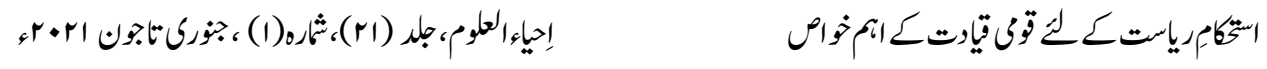

$$
\text { رياست كامننو مغهوم }
$$

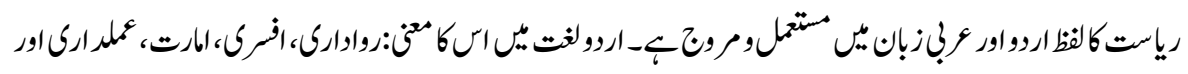
كومتبيانكياكياك-

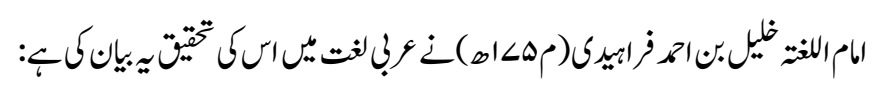

"راس كل شئى اعلاه ويقال انا راسهم ورئيسهم و تراست عليهم و راسونى على انفسهم"'

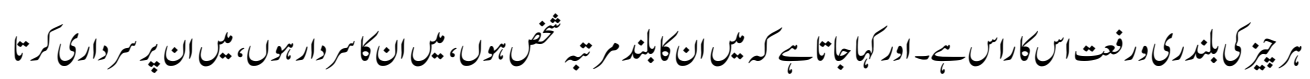

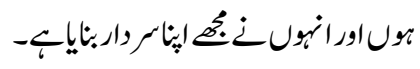

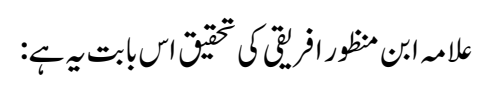

"اذا استقام رئيسهم المدبر لامور هم صلحت احوالهم باقتدائهم ويقال ان الرياسة تنزل من السما

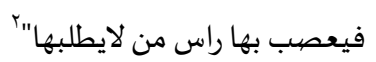

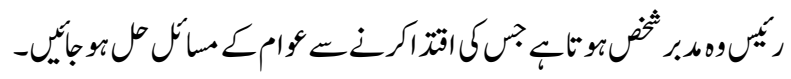

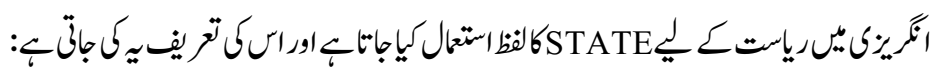

"The state is community of persons, more or less numerous, permanently occupying a definite portion of territory, independent of external control and possessing an organized government to which the great body of inhabitants render habitual obedience."

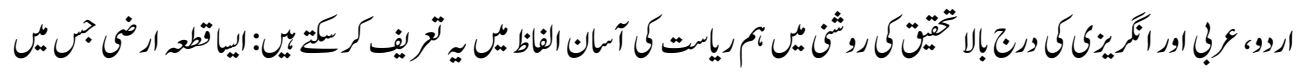

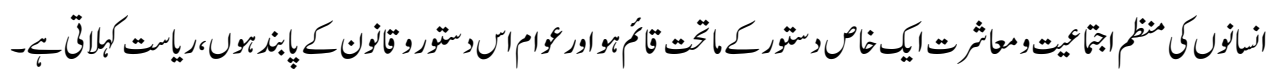

$$
\begin{aligned}
& \text { اسلارياست كى تر ليف }
\end{aligned}
$$


قال الجمهور: دار الإسلام هي التي نزلها المسلمون، وجرت علهها أحكام الإسلام 4

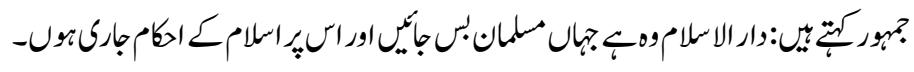

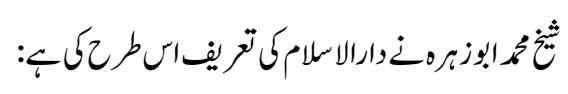

115 .

"دارالاسلام هى الدولة التى تحكم بسلطان المسلمين و تكون المنعة و القوة فهيا للمسلمين"

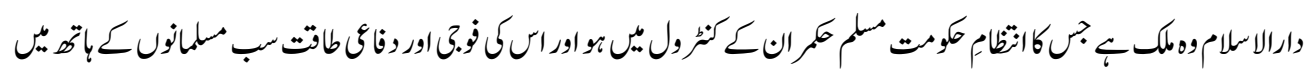

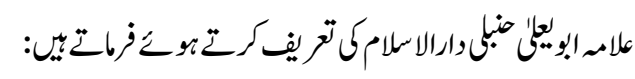
"وكل دار كانت الغلبة فيها لاحكام الاسلام دون احكام الكفر، فهى داراسلام6"

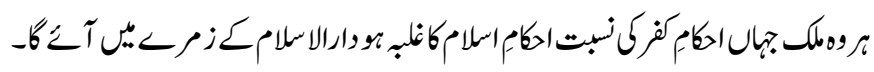

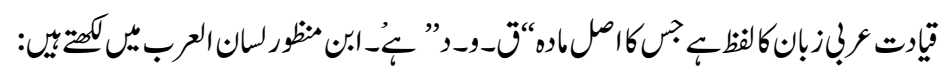

"القود:نقيض السوق يقود الدابة من امامها ويسوقها من خلفها فالقود من امام والسوق من خلفـ قدت الفرس

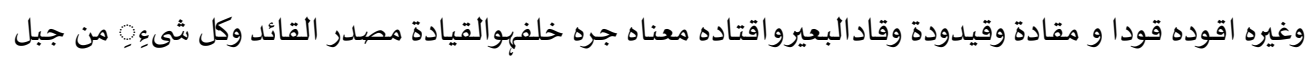

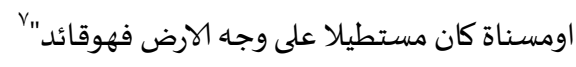

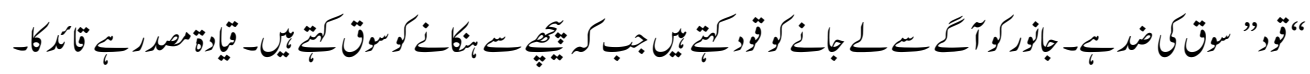

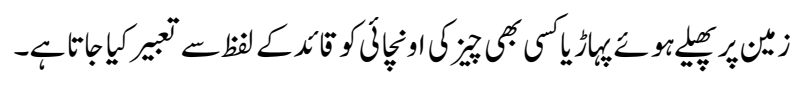




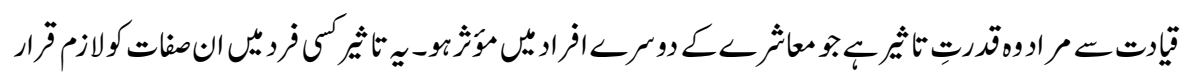

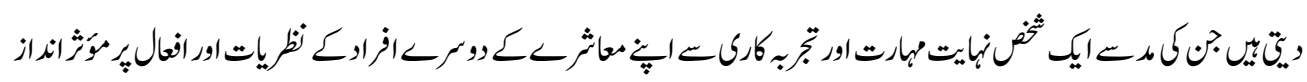

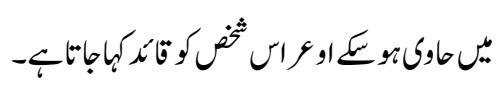

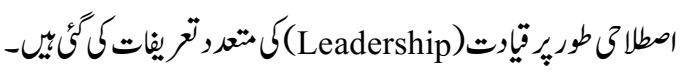
"عرفت القيادة بانها القدرة على التاثير في الاخرين من اجل تحقيق الامداف المشتركة؛"

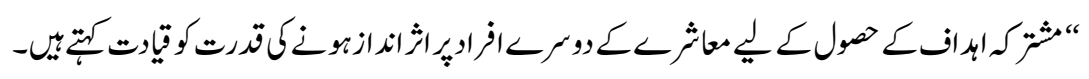

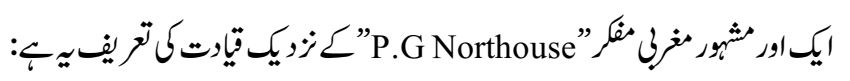

"Leadership is a process whereby an individual influence a group of individuals to achieve a common goal" 9

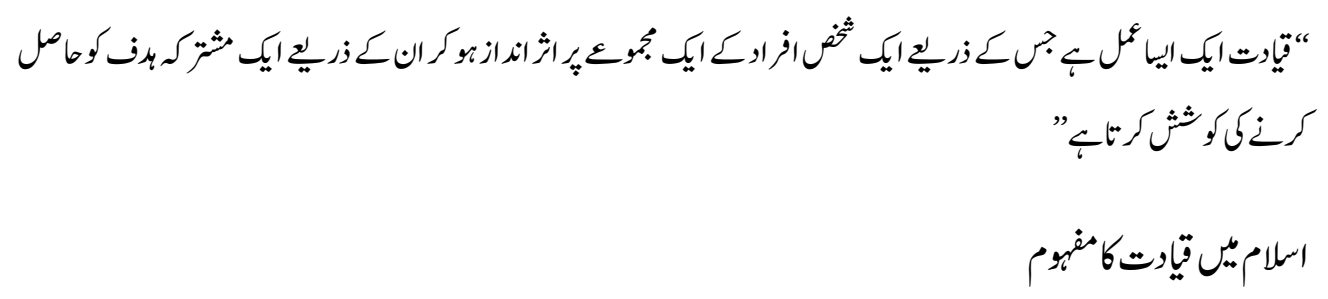

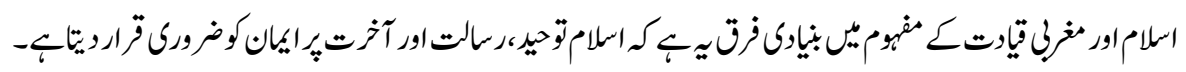

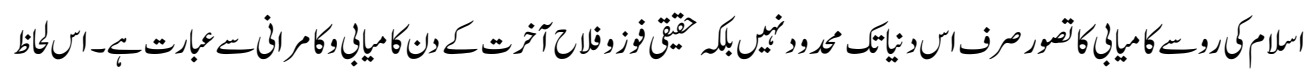

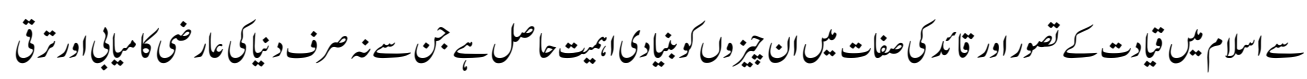

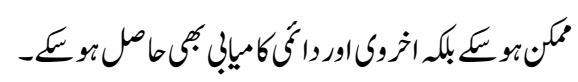

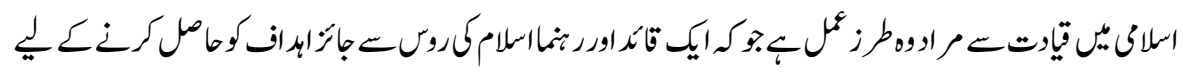

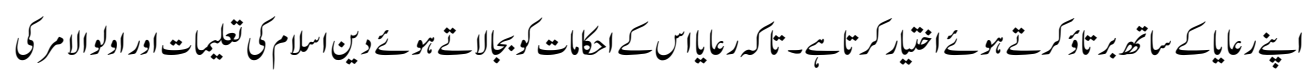

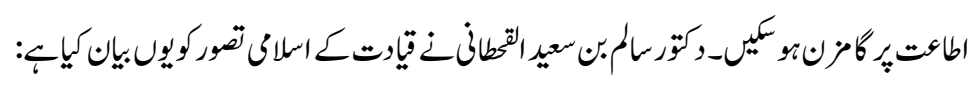




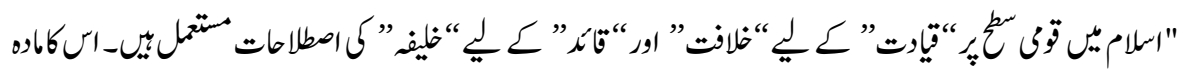

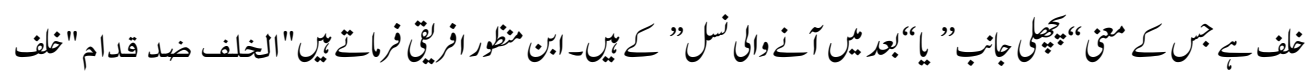

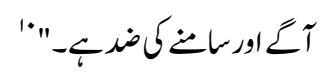

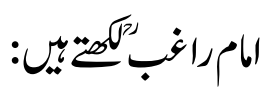

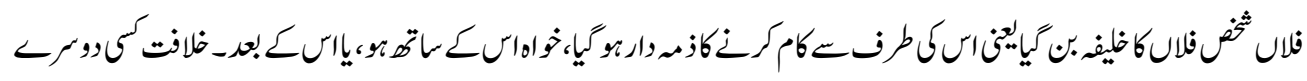

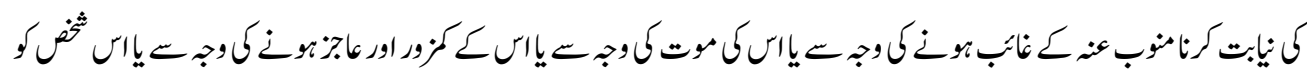

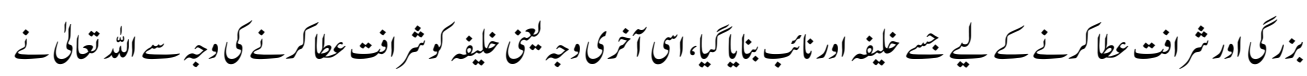

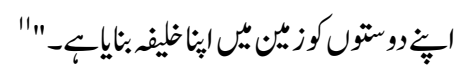

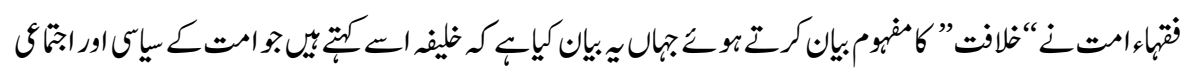

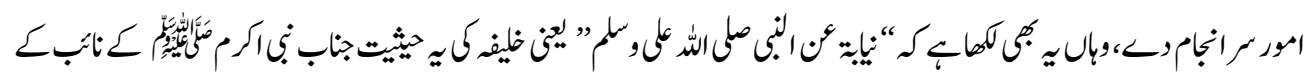
طوريرنوك-

$$
\text { اسلاقرياستي قوىقيارتتكضرورتوانميت }
$$

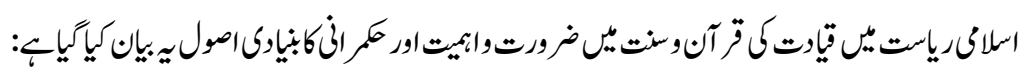

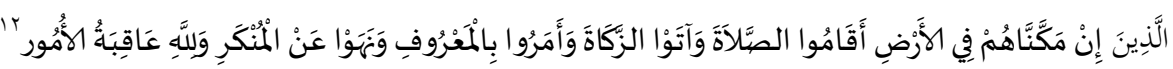

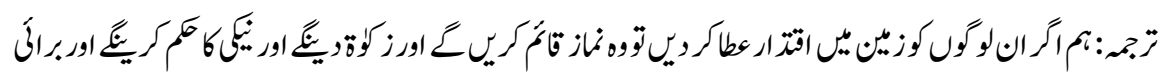

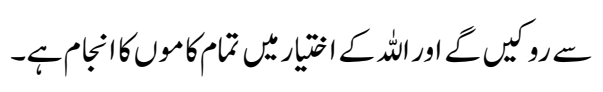

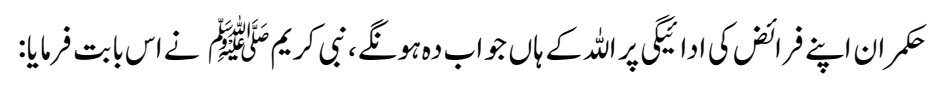

"الكلكم راع و كلكم مسئول عن رعيته فالامام الذى على الناس راع وهو مسئول عن رعيته 13" 


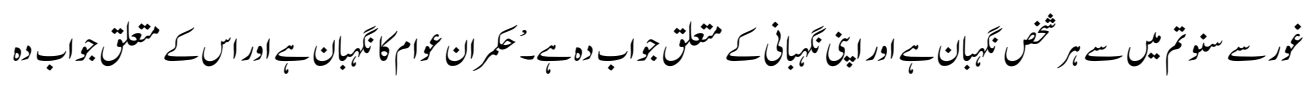

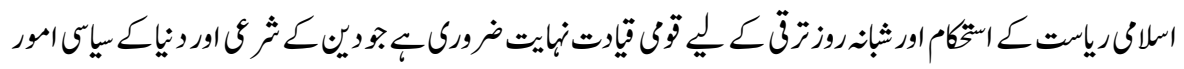

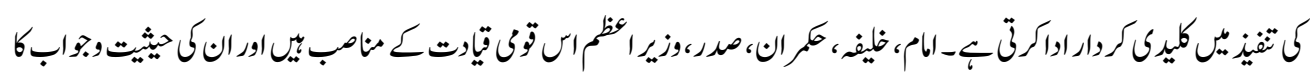

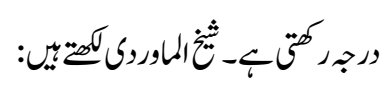

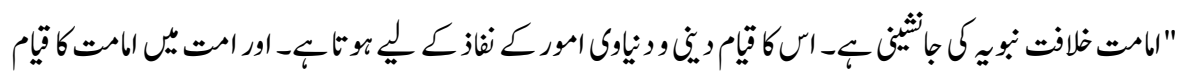

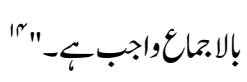

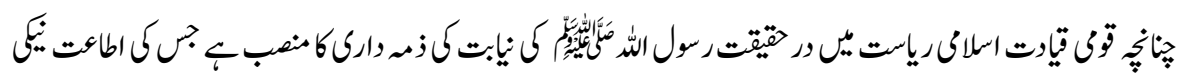

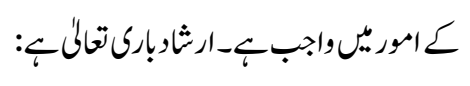

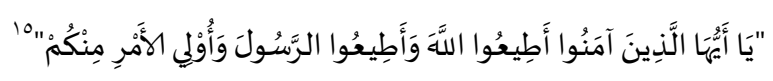

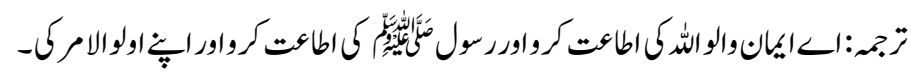

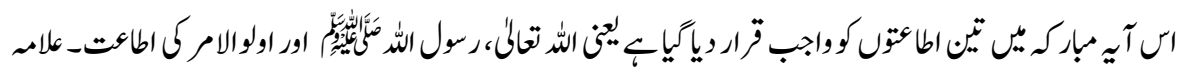

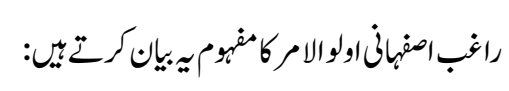

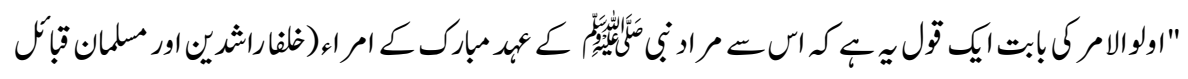

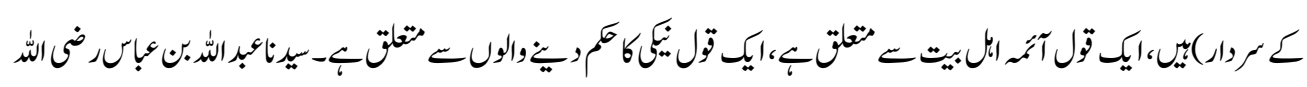

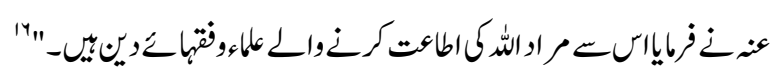

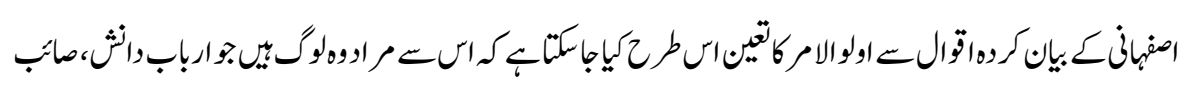

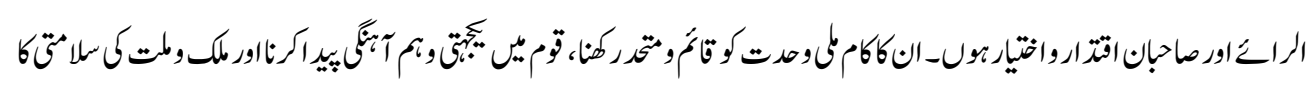

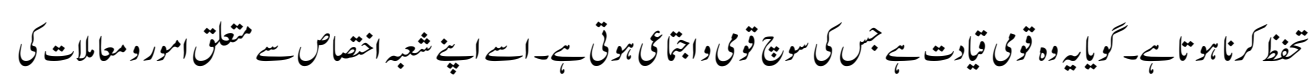

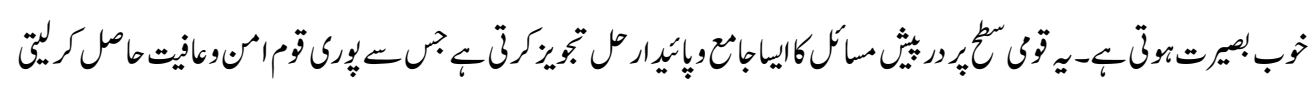




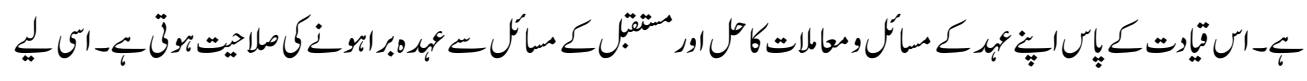

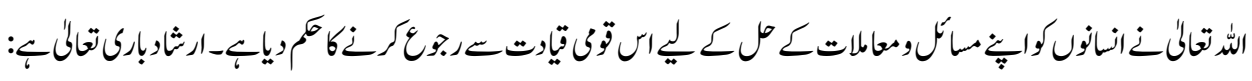

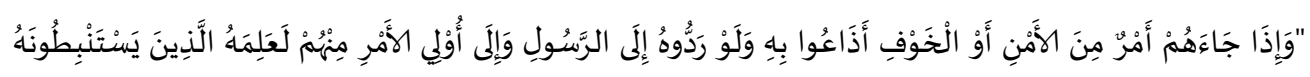

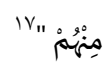

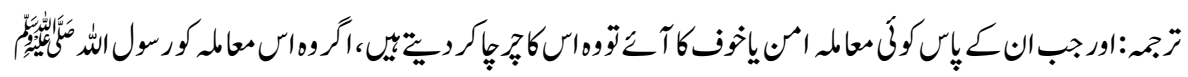

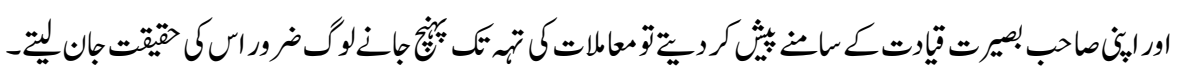

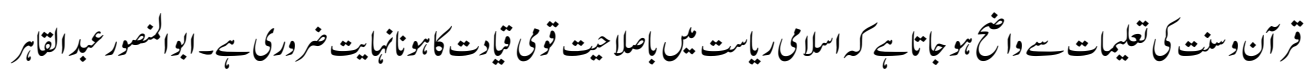

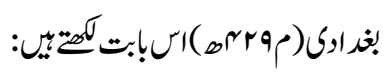

"انه لابد للمسلمين من امام ينفذاحكامهم ويقيم حدودهم ويغزى جيو شهم و وج الايامى ويقسم الفئى بينهم" "1

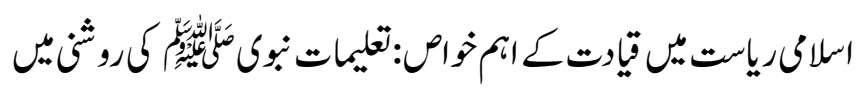

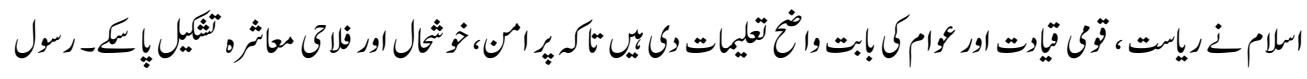

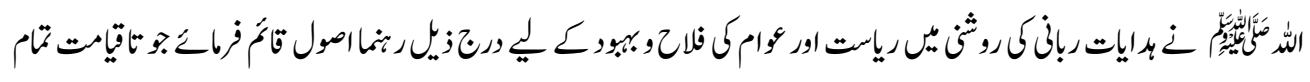

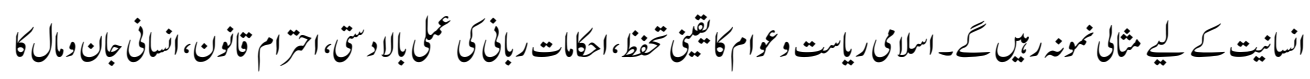

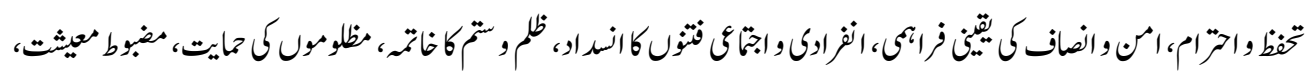

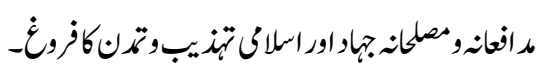

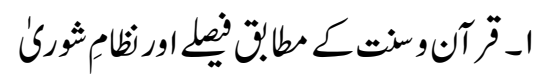

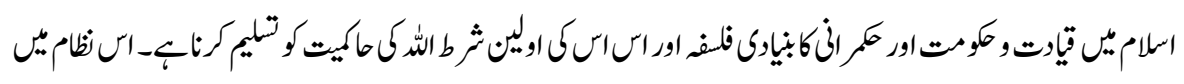

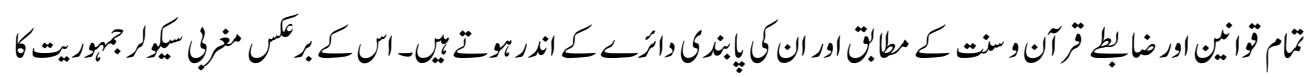

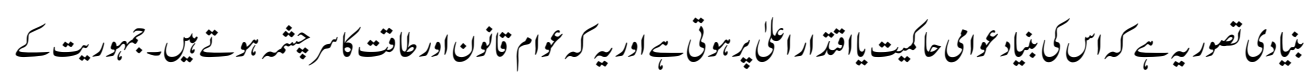

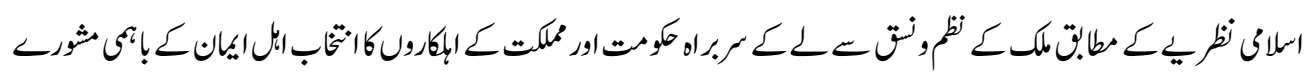




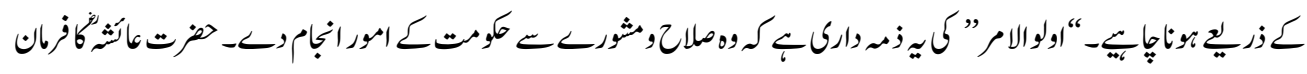

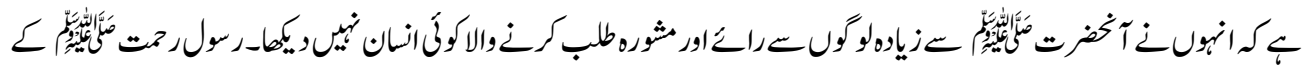

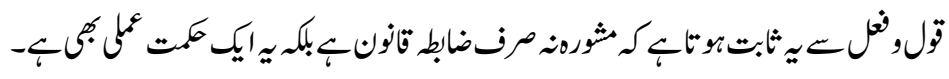

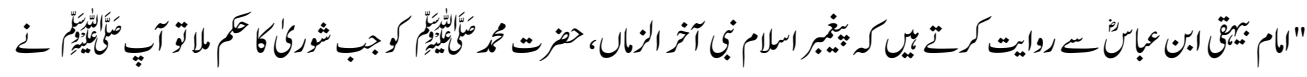

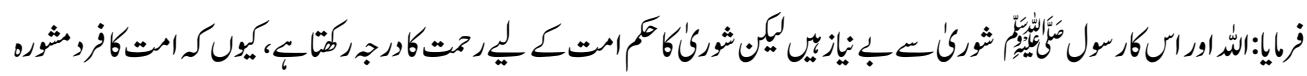

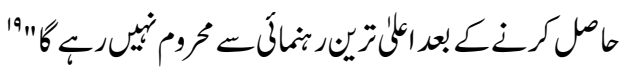

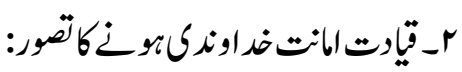

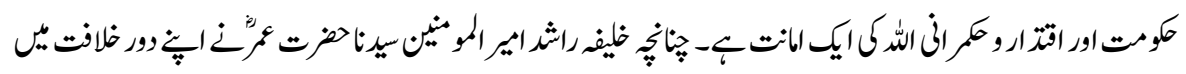

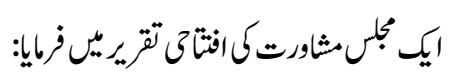

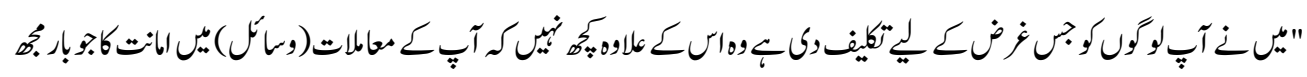

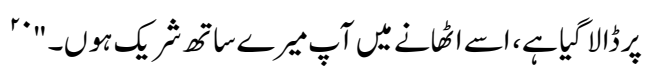

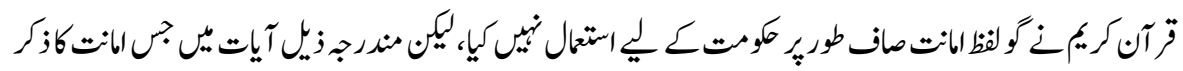

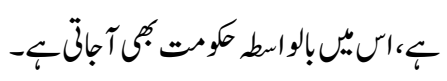

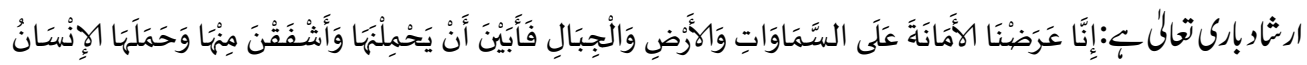

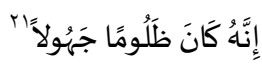

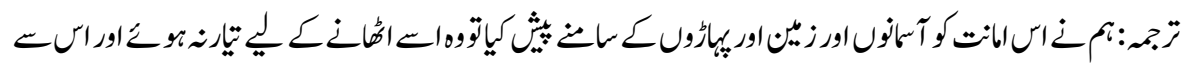

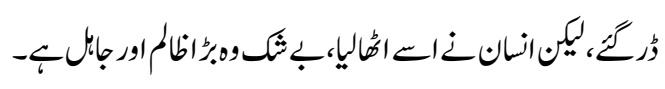

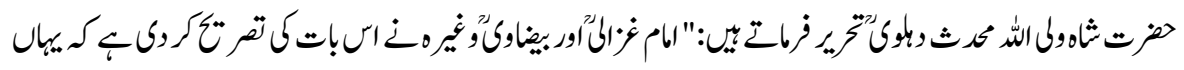

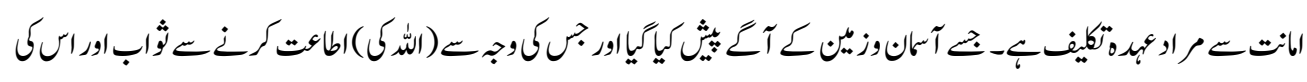




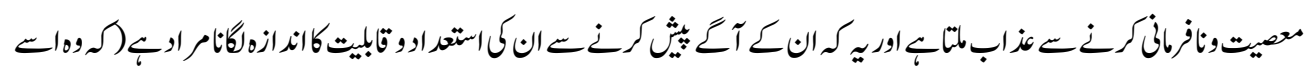

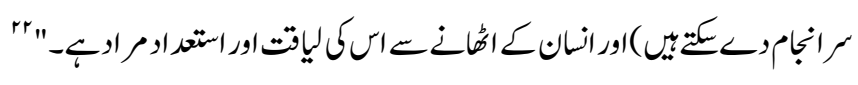

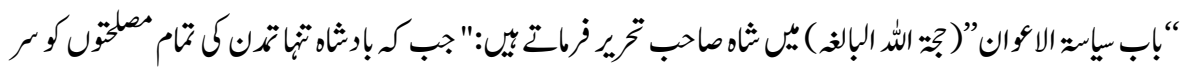

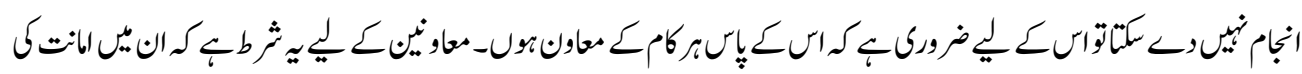
مغتتمو-"

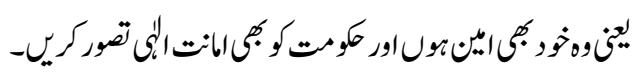

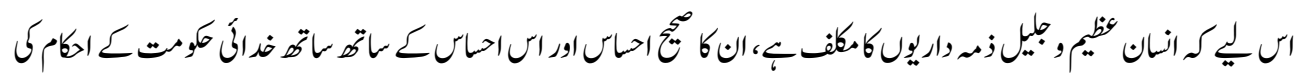

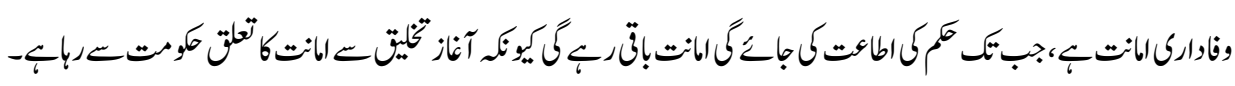

$$
\text { م. ضابط اخلاق اور وستور العمل }
$$

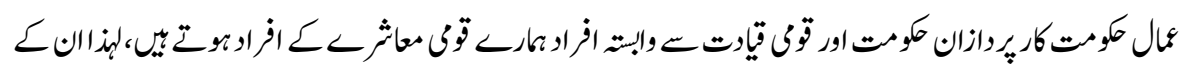

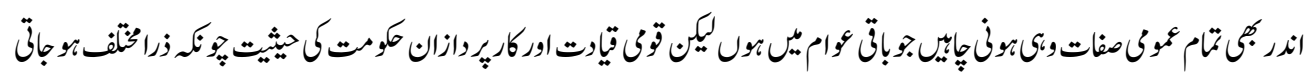

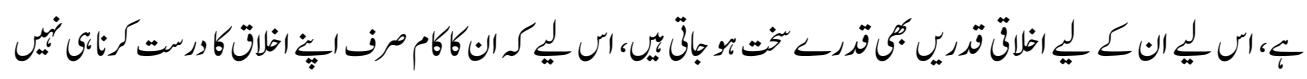

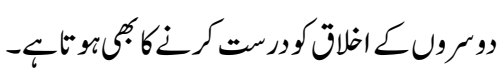

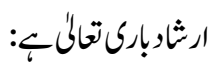

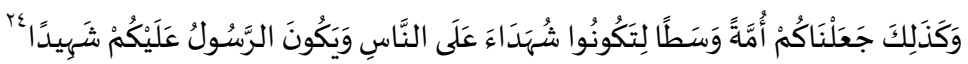

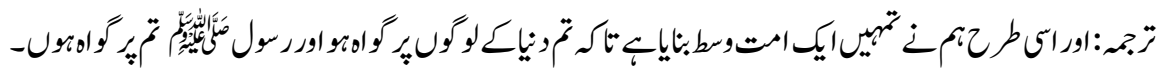

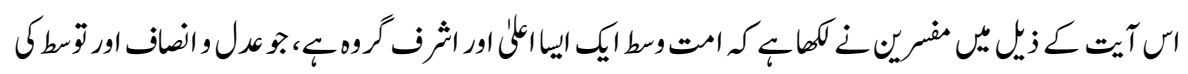

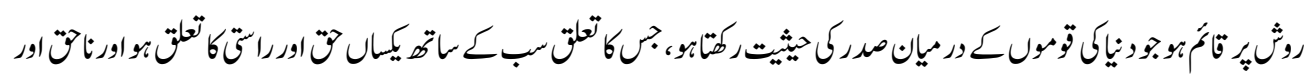

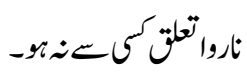




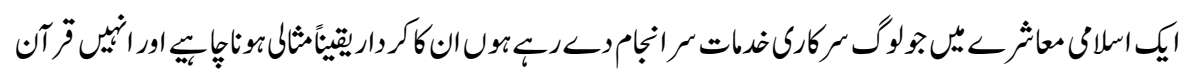

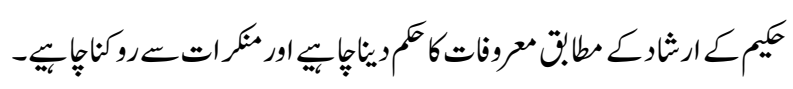

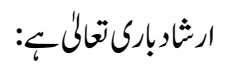

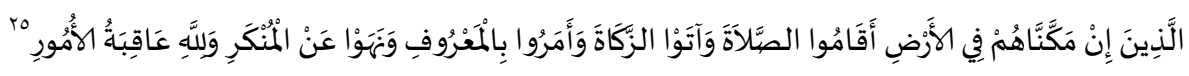

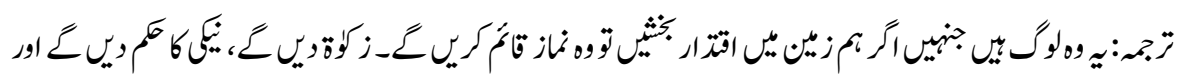

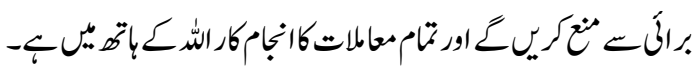

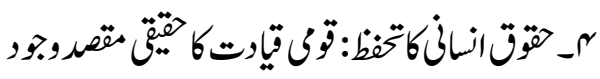

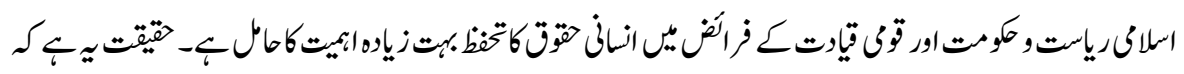

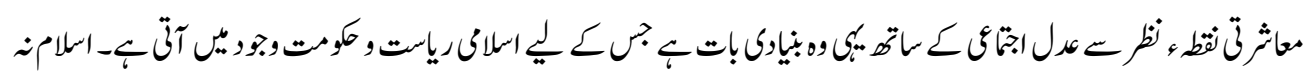

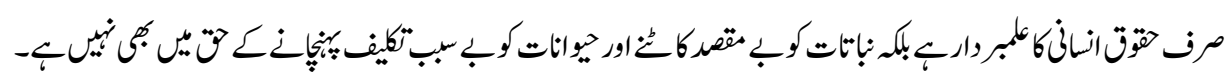

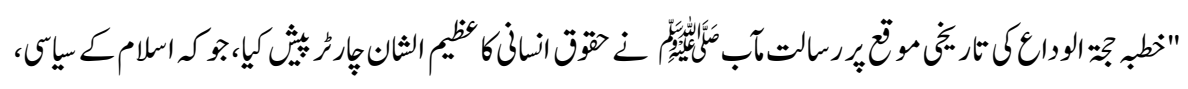

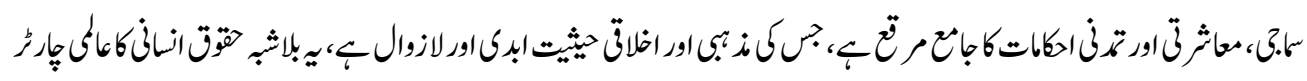

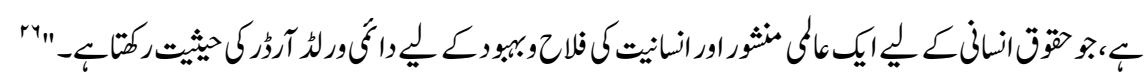

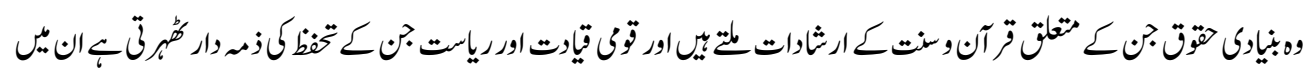

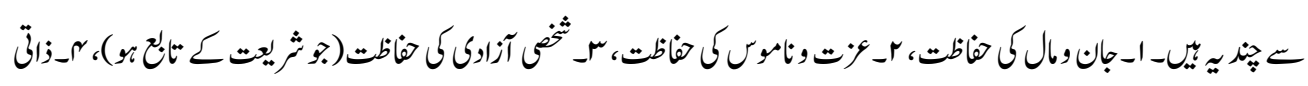

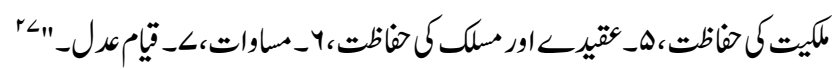

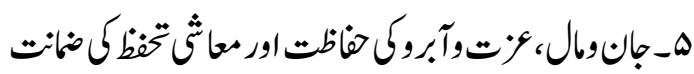

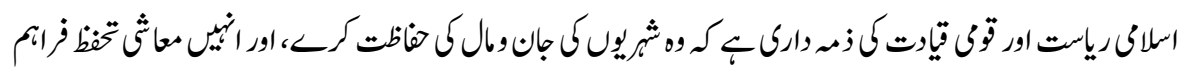

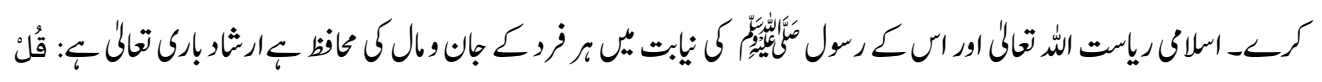




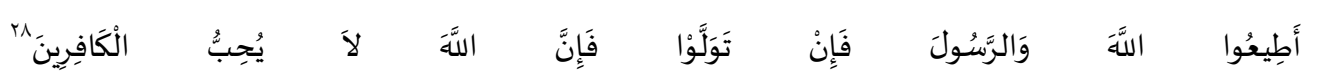

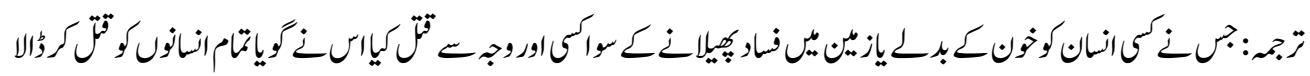

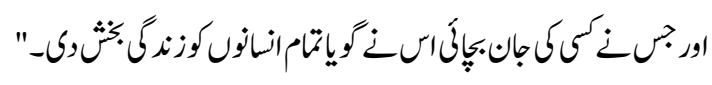

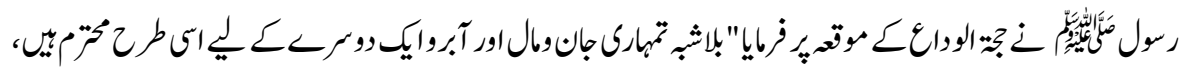

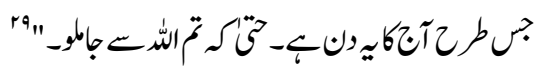

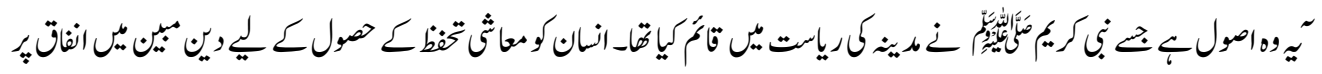

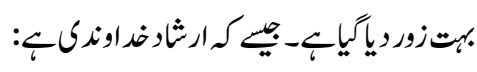

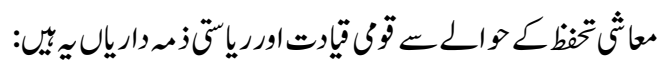

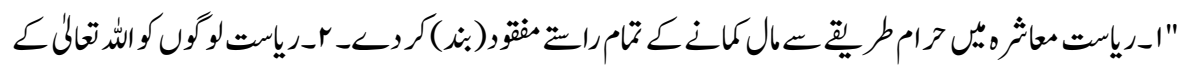

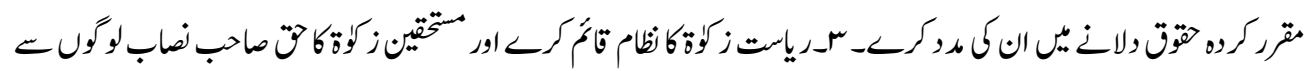

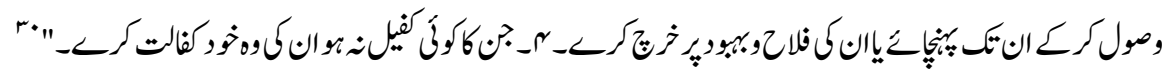

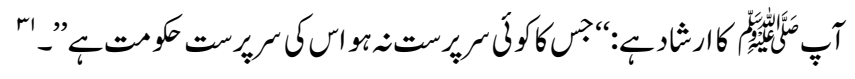

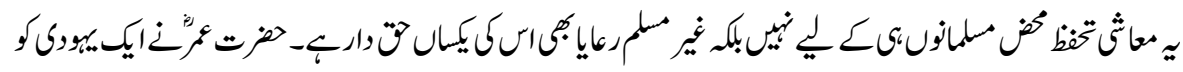

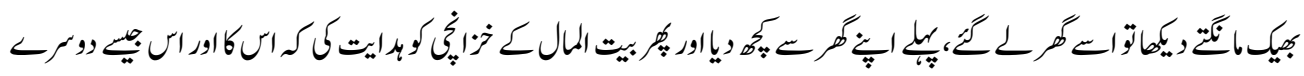

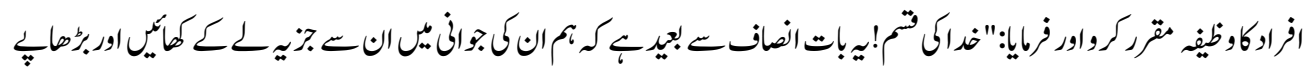

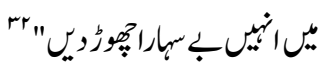

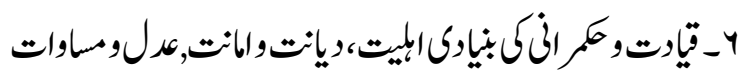

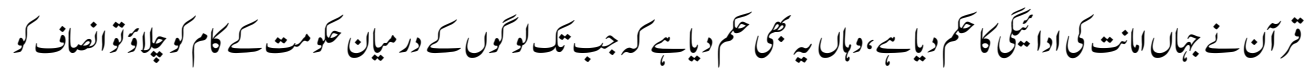

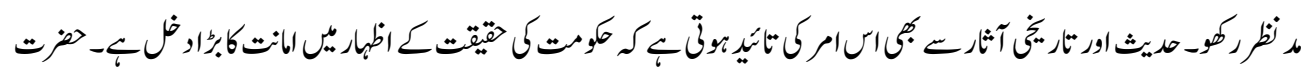




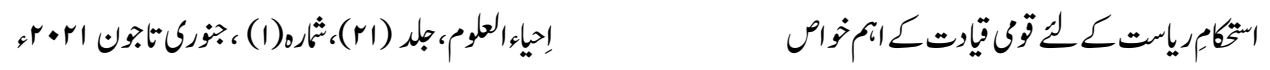

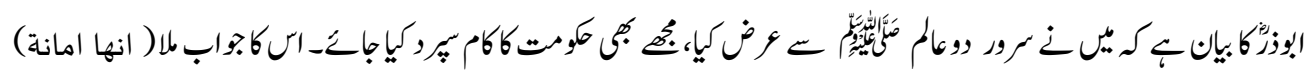

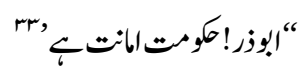

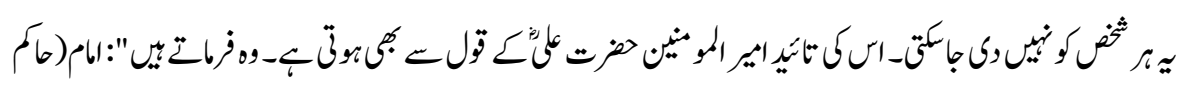

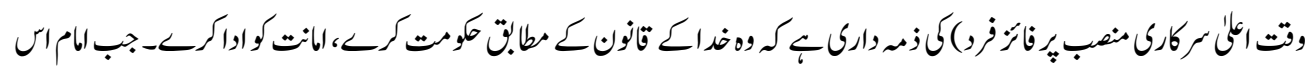

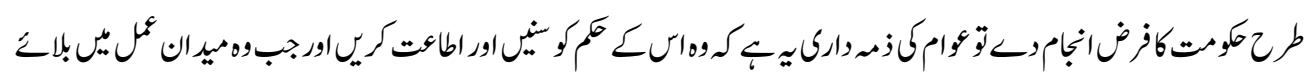
تواسك آوازيربيك كميل"

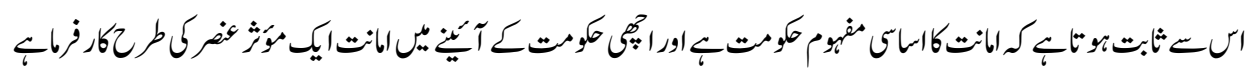

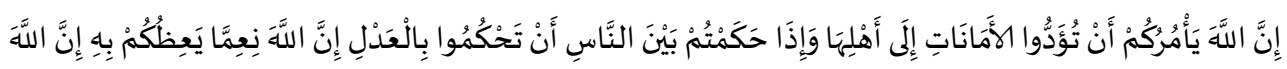
كَانَ سَمِيعًا بَصِيرًا.

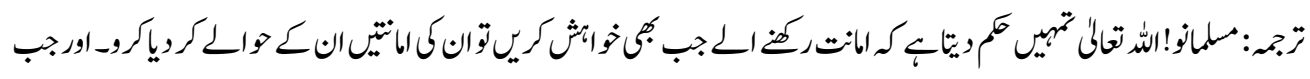

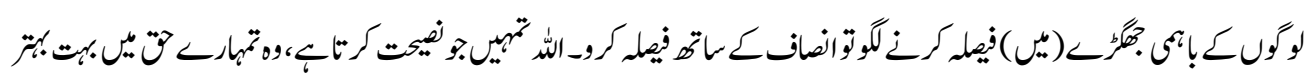

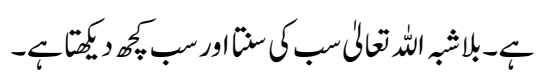

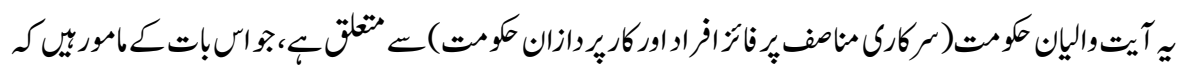

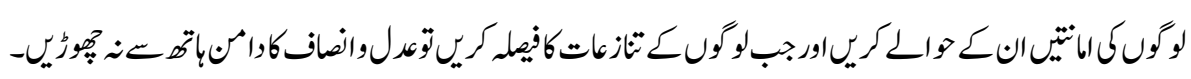

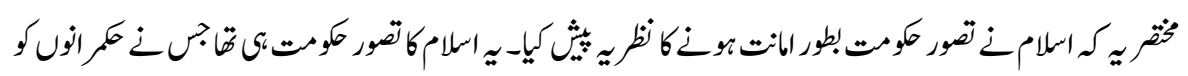

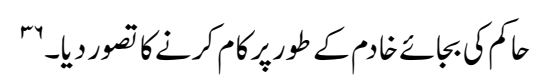

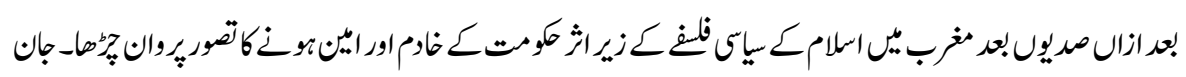

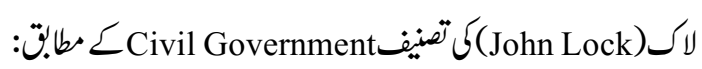

"Government was created in order to carry out the administrative work as a "trust" or an "agent" on behalf of the community" 37 


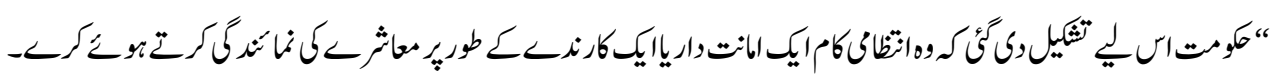

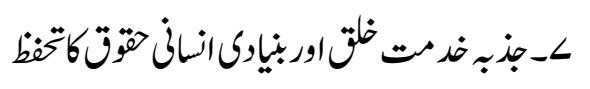

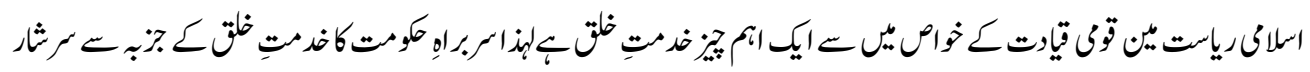

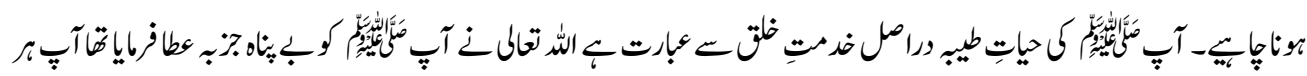

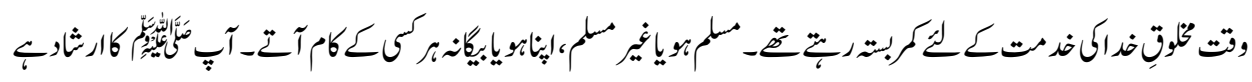

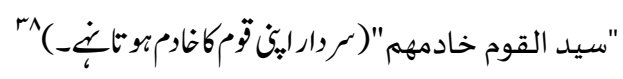

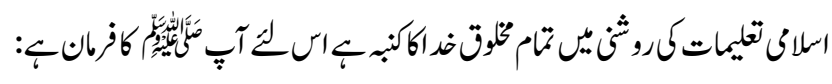
"الخلق كلهم عبال الله فاحب الخلق عندالله من احسن الى عباله" "ra"

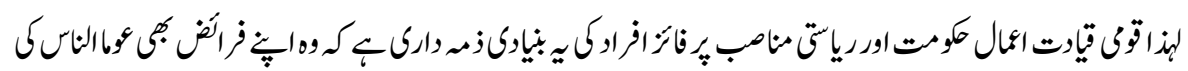

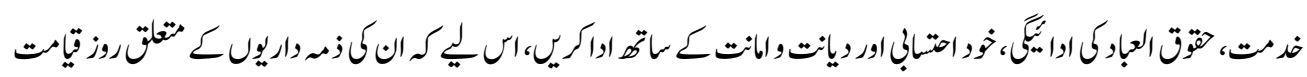

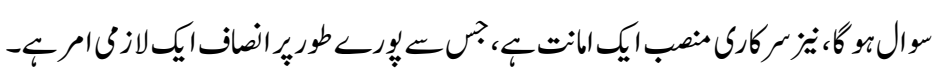

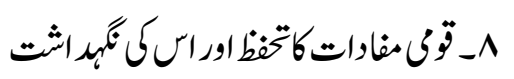

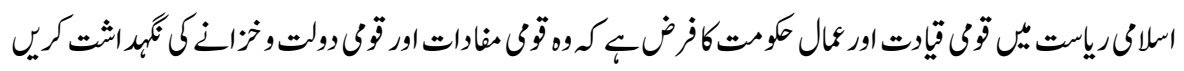

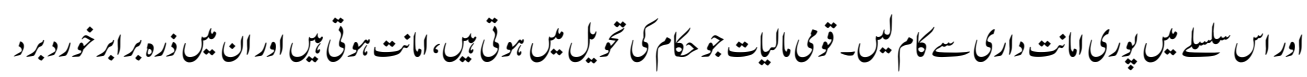
خيانت كزئبي آنقب:

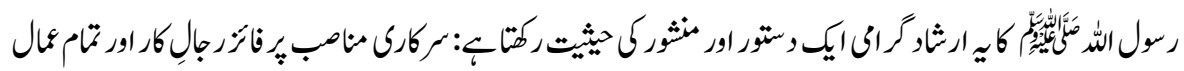

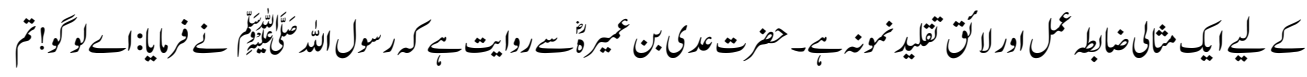

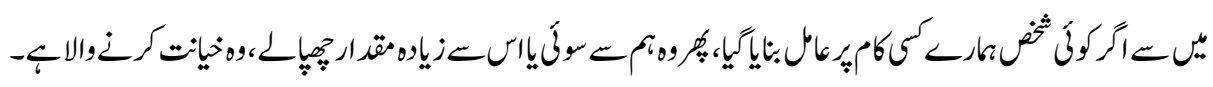




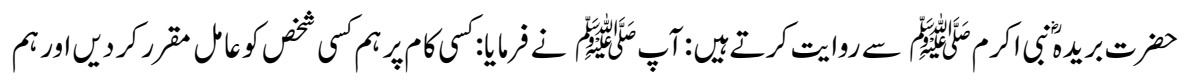

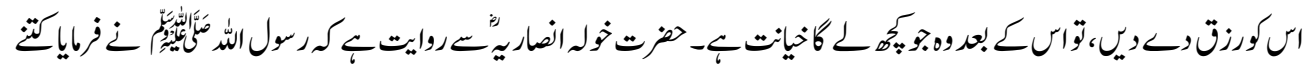

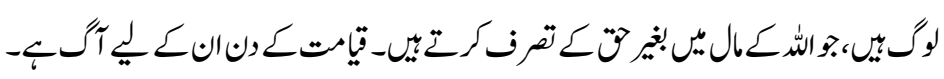

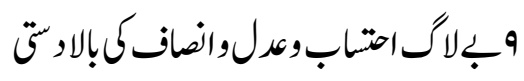

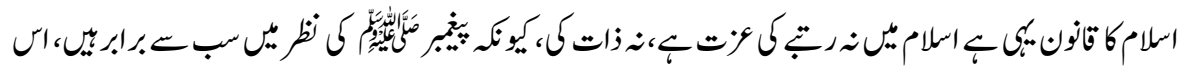

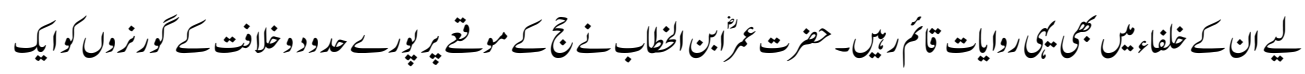

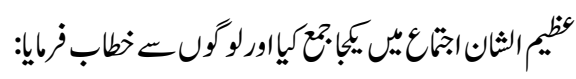

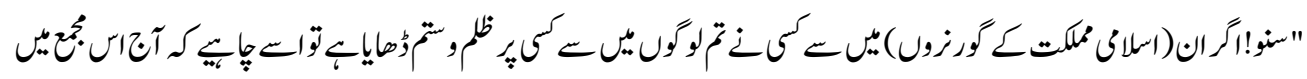

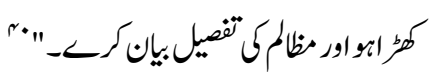

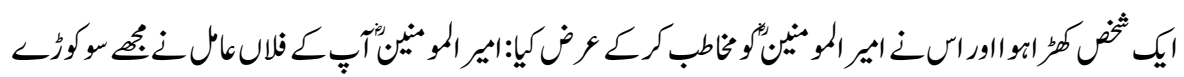

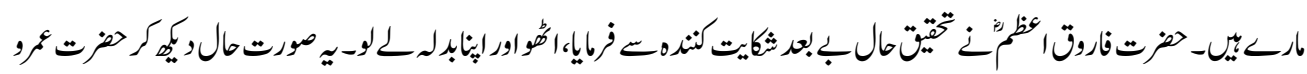

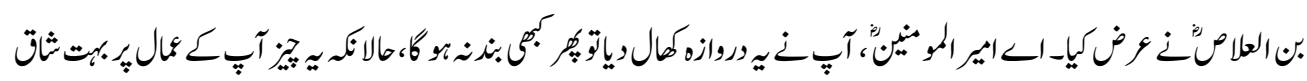

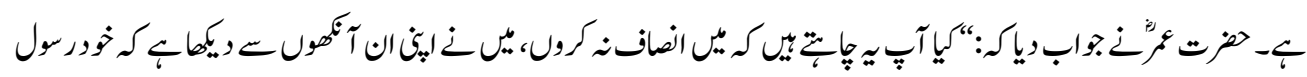

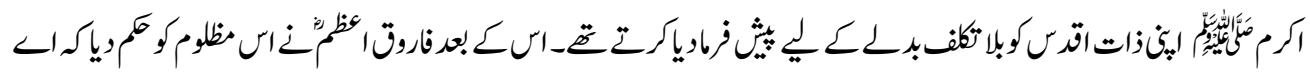

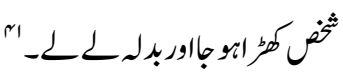

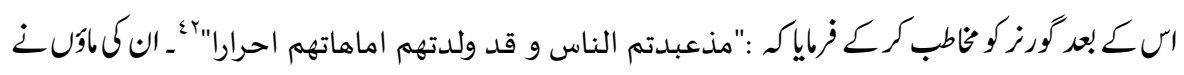

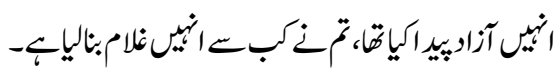

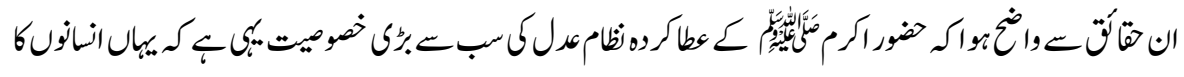

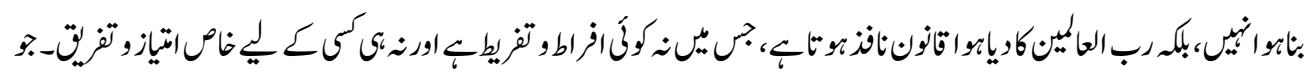

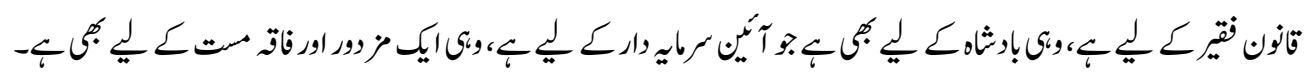




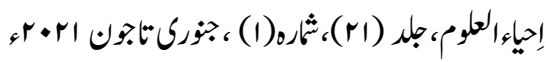

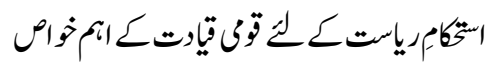

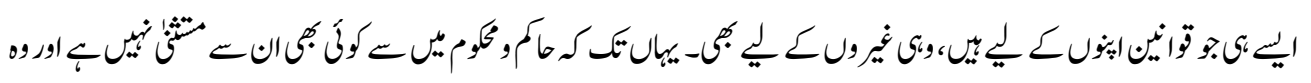

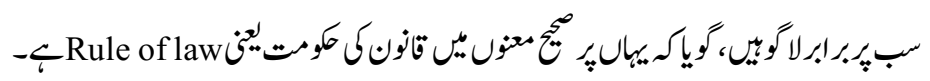

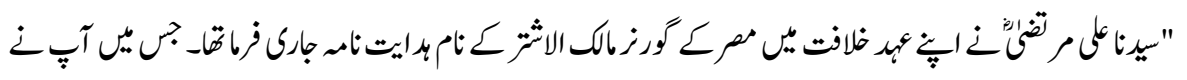

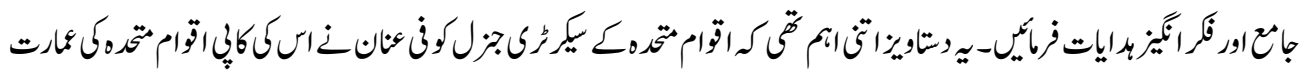

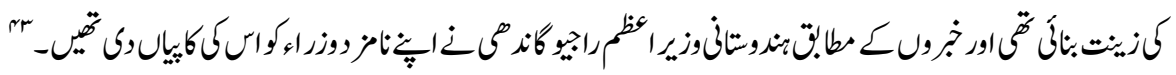

$\leqslant 7$ 


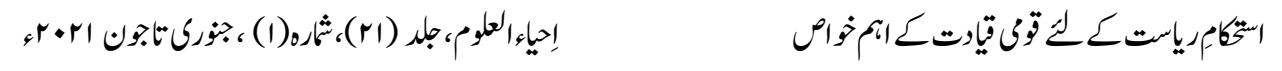

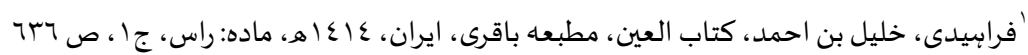

1. Frahīd̄in, Khalīl Bin Ahmd, Kitab al 'Aen, Matb'a Bāqri, Iran, 1414, root word: Ras, Book:1, P. 636

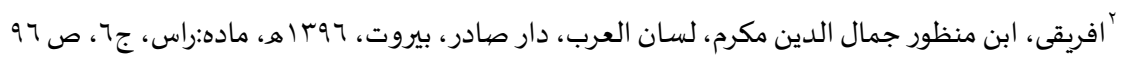

2. Afrīiqīi, Ibn e Manzūr Jamal al-Din Makaram, Lisan al-“Arab, Dār Sadir, Beirut, 1396, Madah: Ras, Book, 6, P. 96

${ }^{3}$ www.definations of state.html

4. Abu Zahrah, Al-'Alāqat al-Dawliah fil Islam, P.56

أبو زهرة، العلاقات الدولية في الهسلام،صها

5.Ibn e Qayyam, ahkām ahl al-zimmah, p. 728

ابنِ قيم، احكام اهل الذمة:LYA،VYN

6.Abu Ya'lā Hambalī, Al-Mu’tamid fi usūl al-Dīn, 276

$$
\text { T ابو يعلى حنبلى، المعتمدفى اصول الدين_YV7 }
$$

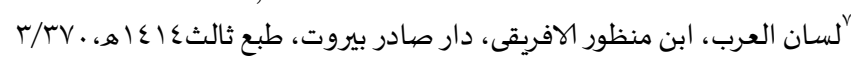

7.Lisan al 'arab, Vol. 3, p. 370

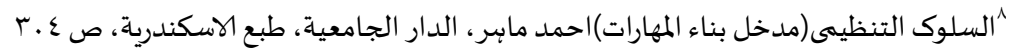

8.Al-salūk al tanzīmī (Madkhal Bina al-mahārāt) Ahmad Mahir, Al-dār al-jāmi'ah (tab a’ al askandriah) P:304

9 Leadership: Theory and practice by PG Northouse, 2013, P:5

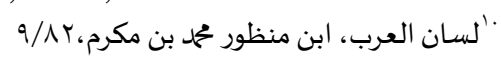

10.Lisān al-'arab, ibn e Manzūr Muhammad Bin Mukaram, vol. 9, p. 82

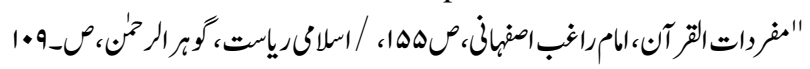

11.Mufardāt al-Qur'an, imam Rāghib Asfahāni, P.155, / Islami Ryasat, Gohar al-Rahman, p.109

12. Al-Quran, 22:41

$$
\text { "سورة الحجبr }
$$

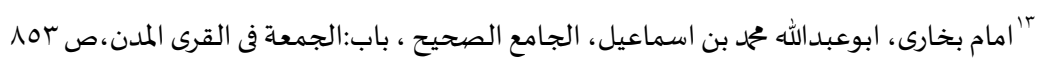

13.Imam Bukhari, Abu Abdullah Muhammad Bin Ismā’il, Al-Jami‘ al-Sahiha, Baab:AL Jumah fil qura al-madan, , P. 853

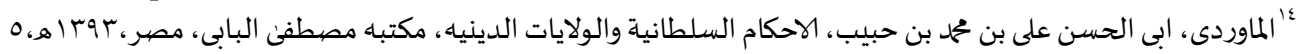
14.Al-Mawardī, abi al Hassan Ali bin Muhammad Bin Habib, al-Ahkam al sultaniah wal walayāt al-dīniyyah, maktabah Mustafa albabi(Egypt, 1393, 5)

15.Al-Qur'an:4:59

$$
\text { ه9:ץ } 15
$$

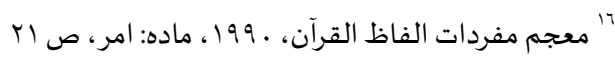




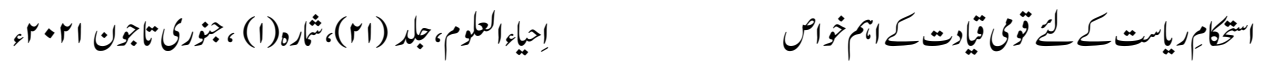

16. Mu‘jam Mufardāt alfāz al-Qur’an, Mada: amar, p. 21

$$
17
$$

17. Al-Qur'an: 4:83

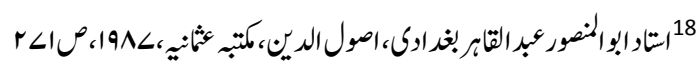

18.Ustad Abu al-Mansoor Abd al-Qahar Baghdadī, usūl al-Dīn, Maktabah Usmania, 1987, $\mathrm{P}: 271$

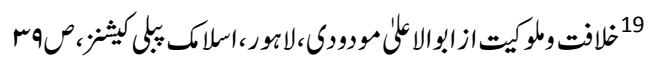

19.Khilafat wa Malūkiyat az Abu al- Ā'la Mawdūdī, Lahore: Islamic Publications, P.39

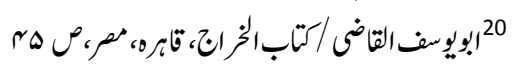

20.Abu Yousaf Al Qadi/ Kitab al-Kharāj, Qairo, Misar: p. 45

21. Al-Qur'an, 33:72

$$
\text { 21 }
$$

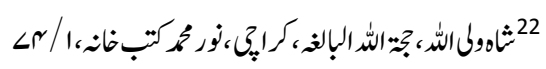

22.Shah Walī Allah, Hajjat ullah al-bāligha, Karachi: Noor Muhammad Kutab Khana, Vol.

1, p. 74

23.Ibid, Vol. 1, p. 133

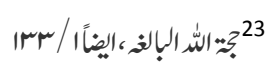

24. Al-Qur'an: 2:143

25. Al-Qur'an : 22:41

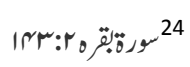

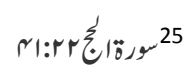

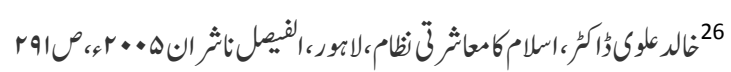

26. Dr. Khalid 'Alv̄ī, Islam ka M 'ashartī Nizām, Lahore: Al-Faysal Nashirān 2005, P. 291

$$
\text { 27 }
$$

27.Ahmad 'abd al-Mat 'ali Nouman, Khutbah Hajat al-widā' ki azmat wa ahmiyat, Roznama Jung Karachi, Special Edition, Yakam1st September,2015

$$
\text { 28 }
$$

28. Al-Qur'an: :32

29.Ibn e Hashām, al-Sīrat al-Nabawiah, Vol. 4, P. 250

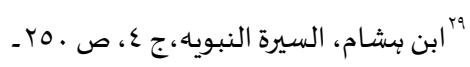

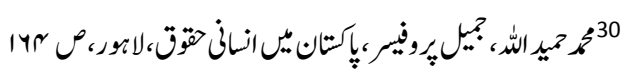

30.Muhammad Hamīd Ullah, Jamīl Prof., Pakistan mayn insani Haqūq, Lahore: P.164

31.Tirmizī, Mishqāt, P.164

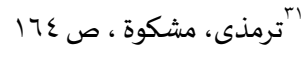

$$
\text { 32 }
$$




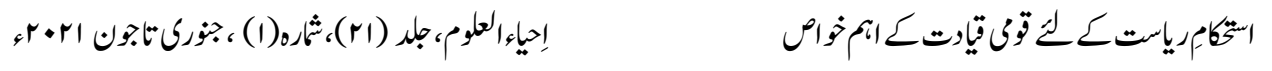

32.Muhammad Nijāt ullah Siddiqui, Dr, Islam ka Nazriya Milkiyat, 1968, Vol. 2 , P.110

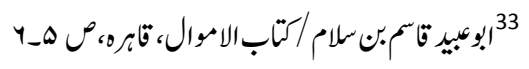

33.Abu 'abaid bin salam/ Kitab al amwāl, Cairo: P. 5,6

$$
\text { 34 }
$$

34. Ibid

$$
\text { 35 بورة/النساء:r }
$$

35. Al-Qur'an:4:58

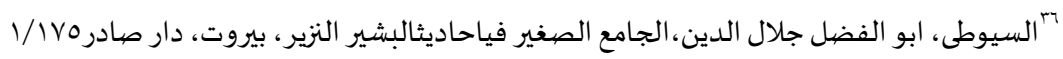

36.Jalal al-Dīn Siyūtī Al-Jami‘ al Saghīr, Beirut: Dār e Sadir Vo. 1, p. 175

37 Mattern, Johannes, Concepts of State, Sovereignty \& Int'l Law, P.17

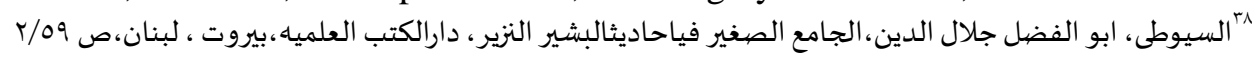

38. Ibid, Vol. 2, P. 59

$$
\text { | }
$$

39.Kanz al 'amāl, Kitāb al-zakāt al, dār al kutab, Hadith:164

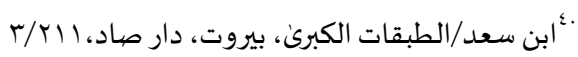

40.Ibn Saad, al-tbqāt al-qubrā, Beirut: Dār e Sadir,Vol. 3, p. 211

$$
\text { ا'يضاً، نيز ابو يوسف القاضى/كتاب الخراج، قابره، ص } 77 \text {. } 71 \text { ، }
$$

41.Ibid, / abu Yousaf al-Qadi, Kitaab al kharja, Cairo: P. 66

$$
\text { 42 }
$$

42.Shahar e Mashāhīr al-Islam, Vol. 3, p. 383

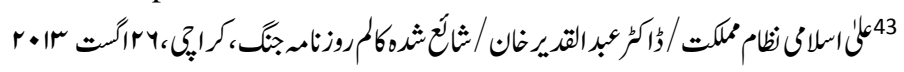

43. Dr. Abdul Qadīr Khan, 'Ala Islami Nizām e Mumlikat, Karachi: Published Column Roznama Jung, 26 Aug, 2013 